\title{
Characterization of seed storage protein patterns of four Iranian Pistachios using SDS-PAGE
}

\author{
Ali Akbar Ehsanpour*, Behrokh Shojaie, Fatemeh Rostami \\ Department of Biology, Faculty of Science, University of Isfahan, Isfahan, Iran; *Corresponding Author: ehsanpou@yahoo.com
}

Received 6 March 2010; revised 10 April 2010; accepted 15 April 2010.

\begin{abstract}
We used SDS-PAGE to evaluate and characterize the protein patterns of seed storage proteins in four pistachios cultivars (Akbari, Ahmad Aghaei, Fandoghi, and Kaleghouchi). Total protein content of pistachio seeds in all cultivars did not show any significant difference. Results of SDS PAGE pattern of a few protein bands were up regulated whereas some other bands showed down regulation. The identified protein patterns may be used protein marker for pistachio cultivars.
\end{abstract}

Keywords: Pistachio; Protein Marker; SDS PAGE

\section{INTRODUCTION}

Pistacia vera L. (pistachio) $(2 \mathrm{n}=32)$ is belong to Anacardiaceae family. Iran is one of the largest producer and exporter of pistachio $(300,000$ tones per year) in the world [1]. Pistachio seed is a very high source of protein, lipid, and vitamins such as vitamin A, B1, B2C, and Niacin. It has also a high percentage of potassium, calcium and phosphorous. Iranian pistachios are different in sizes and shape and they are divided into four major groups including round (Fandoghi), jumbo (Kaleghouchi) and long (Akbari, Ahmad Aghaei) (http://en.wikipedia. org/wiki/Pistachio and http://www.sahravi.com/pistachio iranian-pistachio.htm).

Plant storage proteins can be classified into two classes; seed storage proteins (SSPs) and vegetative storage proteins (VSPs). SSPs are a set of proteins that accumulate at high levels in seeds during the late stages of seed development, whereas VSPs are proteins that accumulate in vegetative tissues such as leaves, stems and tubers, depending on the plant species. SSP genes were classic targets for work on plant molecular biology. Their abundant expression in seeds allowed for easy detection of the gene transcripts and cDNA cloning dur- ing research on plant molecular biology in late 70's to early 80 's. Characterization of germplasm using biochemical fingerprinting has got special attention due to its increased used in crop improvement and the selection of desirable genotypes for breeding crops. The use of genetic markers and protein profiling has also been successfully used to resolve the taxonomic and evolutionary problems of several crop plants [2-6]. The seed storage protein analyses helps in identification and characterization of diversity in crop varieties, cultivars and their wild varieties and also provides information on phylogenetic relationship of the accessions. It is also known that variation in protein bands provide information on the relationship among the used seeds collected from various geographical regions [6-8]. There are different amounts of storage proteins in all plant seeds. They play two main roles including nitrogen and energy source and defense against insects and pathogens such as bacteria and fungi.

Since, seed storage protein analysis can be a useful tool for identification of species, varieties and cultivars, in this study we investigate the protein pattern in four Iranian pistachios seeds (Akbari, Ahmad Aghaei, Fandoghi, Kaleghouchi) in order to find protein bands as markers for cultivar characterization.

\section{MATERIALS AND METHODS}

\subsection{Plant Material}

Fresh mature seeds of Pistachio cultivars including Akbari, Ahmad Aghaei, Fandoghi, and Kaleghouchi were harvested from pistachio garden in Ardestan, Isfahan, Iran.

\subsection{Extraction of Seed Proteins}

Seed coats from fresh ten seeds from each cultivar were removed and kernels were then grounded in liquid nitrogen with a mortar and pestle. The seed storage proteins from each cultivar was extracted with cold acetone 
by stirring the mixture at $50 \mathrm{rpm}$ at $4^{\circ} \mathrm{C}$ for $48 \mathrm{~h}$, and subsequently the defatted powder of each cultivar of pistachio was air dried at room temperature for $8 \mathrm{~h}$. Next, the dry powder was suspended in 1:20 (w/v) of $1 \mathrm{ml}$ of $50 \mathrm{mM}$ Tris- $\mathrm{HCl}$ buffer containing $1 \mathrm{mM}$ DTT, $2 \mathrm{mM}$ EDTA, 2 mM 2-Mercaptoethanol, pH 7.5. The suspension was stirred at $50 \mathrm{rpm}$ at $4^{\circ} \mathrm{C}$ overnight and was centrifuged for $25 \mathrm{~min}$ at $14000 \mathrm{rpm}$ at $4^{\circ} \mathrm{C}$. The precipitate was discarded and the supernatant was used for total soluble protein (mg g1-dp or defatted powder) assay according to modified Bradford method [9] described by Olson and Markwell [10] using bovine serum albumin as standard protein and SDS-PAGE analysis. SDS-PAGE was performed using 12\% separating and 5\% stacking gels [11]. After electrophoresis at $120 \mathrm{~V}$, protein bands were stained using silver nitrate and finally the relative density of protein bands were analyzed by ImageJ (http: //rsb.info.nih.gov/ij/). The intensity of protein bands in different samples were analyzed by NTSYSPc2 program. In order to augment accuracy, all experiments including exaction and SDS-PAGE were repeated at least four times. Data were subjected to ANOVA and the mean differences were compared by Duncan test at $\mathrm{P}<0.05$.

\section{RESULTS}

To investigate variations among four Iranian pistachio cultivars, seed storage proteins from cultivar Akbari (A), Ahmad Aghaei (AA), Fandoghi (F) and Kaleghouchi (K) were analyzed. As shown in Figure 1, no significant difference in total protein content was observed in four pistachio cultivars.

The SDS-PAGE protein patterns of four pistachio cultivars showed changes in seven protein bands (Figure 2). Subsequently, the relative levels of protein concentra-

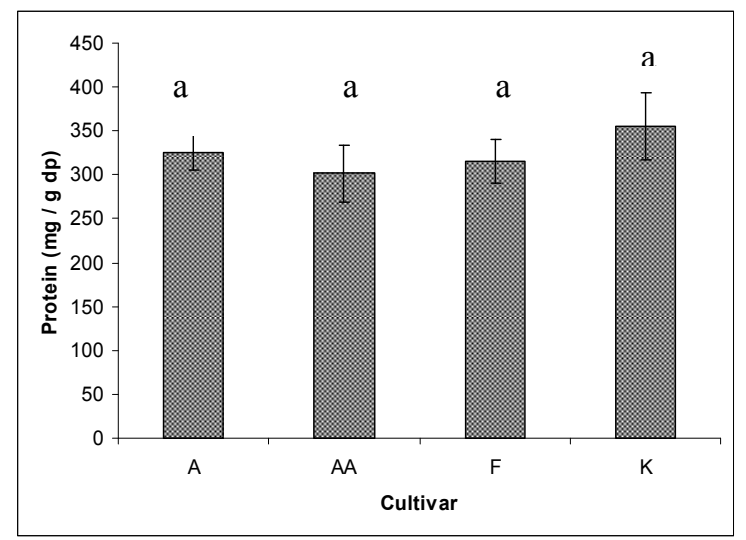

Figure 1. Total soluble protein in four pistachio cultivars Akbari (A), Ahmad Aghaei (AA), Fandoghi (F) and Kaleghouchi $(\mathrm{K})$, defatted powder (dp). Values are the means \pm SE. Similar letters (a) indicate no significant difference $(\mathrm{P}<0.05)$ based on Duncan test in four pistachio cultivars. tion of these seven protein bands were analyzed by Image J program (Figure 3). Five protein bands (1, 2, 3, 4 and 5) with approximate MW 45, 33, 32, 27 and $20 \mathrm{kDa}$ respectively, showed maximum expression level in cultivar AA. Protein bands of 6 and 7 with approximate MW 16 and $15 \mathrm{kDa}$ showed maximum expression level in cultivar A, respectively. However, bands 3 and 4 were not detectable in cultivars $\mathrm{K}$ and $\mathrm{A}$, while they were detected in the other cultivars. Protein bands 2, 5 and 6 had lower expression level in cultivar F. The minimum level of protein band 1 was observed in cultivar $\mathrm{A}$ and protein band 7 in cultivar $\mathrm{K}$.

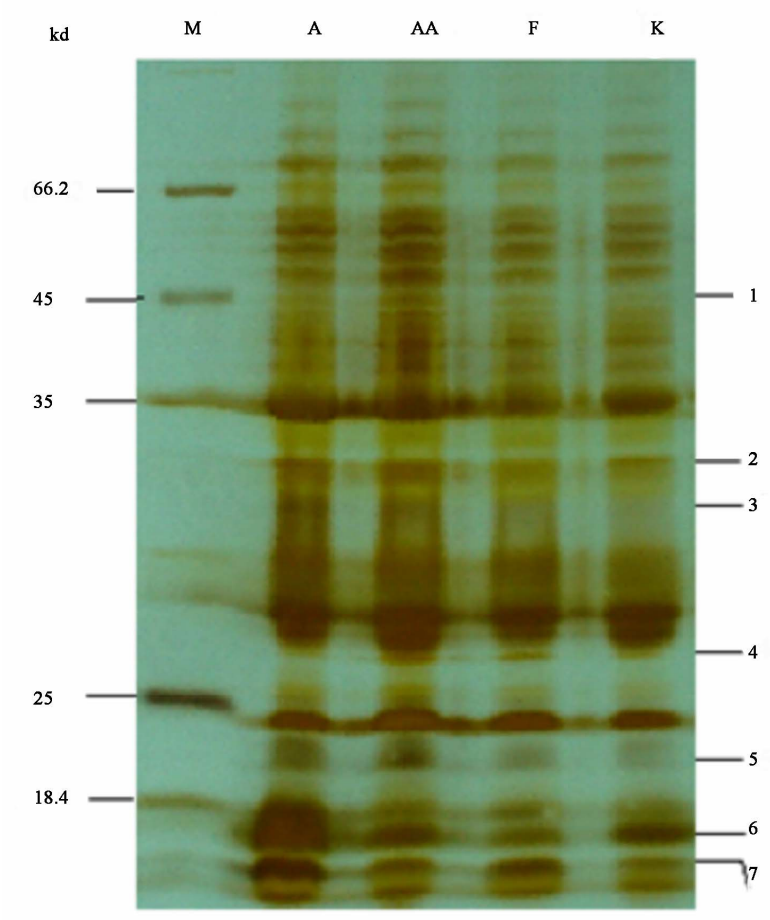

Figure 2. SDS-PAGE pattern of four pistachio cultivars Akbari (A), Ahmad Aghaei (AA), Fandoghi (F) and Kaleghouchi (K) protein marker $(\mathrm{M})$.

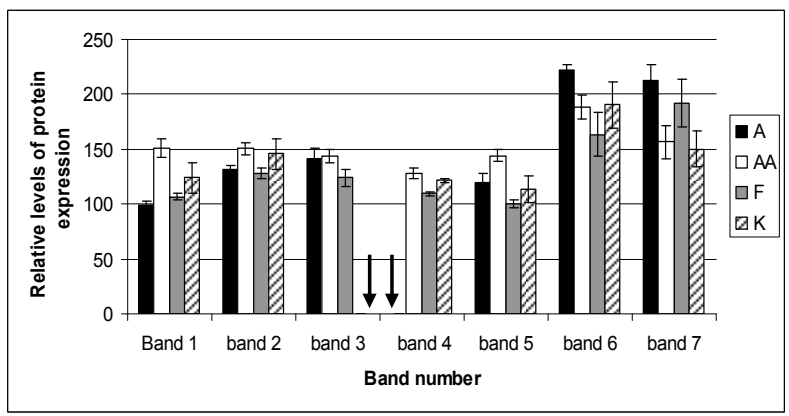

Figure 3. Relative levels of protein expression of pistachio cultivars Akbari (A), Ahmad Aghaei (AA), Fandoghi (F) and Kaleghouchi $(\mathrm{K})$. Values are the means $\pm \mathrm{SE}$ of proteins bands from three independent experiments. 


\section{DISCUSSION}

Electrophoresis of proteins is a powerful tool for identification of genetic diversity and the SDS-PAGE is particularly considered as a reliable technology because seed storage proteins are highly independent of environmental fluctuations $[12,13]$. Seed protein patterns can also be used as a promising tool for distinguishing cultivars of particular crop species $[14,15]$. However, only a few studies indicated that cultivar identification was not possible with the SDS-PAGE method [16]. The SDSPAGE is considered to be a practical and reliable method for species identification [17].

According to the results of the SDS-PAGE, the overall pattern of seed storage-proteins showed the diversity of pistachio cultivars. The diversity in seed storage proteins has also been reported by Khan et al. for wheat varieties [18]. Moreover, identification of three wheat genotypes including ILC-195, CM-2000 and CM-98/99 has also been reported by protein markers [19].

Since in mature seeds, type and amount of proteins are more constant than other plant tissues [20] therefore, the SDS-PAGE pattern of seed storage proteins of pistachio showed polymorphism on the basis of difference in protein intensity among genotypes. The presence or absence of protein bands has also been applied for detection of polymorphism of Brassica cultivars [21].

The present investigation revealed variation in different cultivars of pistachio seeds with regard to their total seed protein profiles. Regarding interspecific variation among cultivars this investigation revealed some variations. The genetic affinities within cultivars of the same species generally corroborated the morphological analysis. Similar to our finding the result of differentiation of yellow sarson and brown seeded types of Brassica clearly separated the yellow seeded and brown seeded varieties by SDS PAGE [22]. However, we can conclude that, SDS-PAGE can reveal the differences among seed storage proteins of pistacia cultivars.

\section{ACKNOWLEDGEMENTS}

Authors wish to thank University of Isfahan for their support.

\section{REFERENCES}

[1] Ehsanpour, A.A., Tavasoli, M. and Arab, L. (2008) Sex determination of Pistacia vera L. using ISSR markers. Malaysian Applied Biology, 37(2), 25-28.

[2] Ladizinsky, G. and Hymowitz, T. (1979) Seed protein electrophoresis in taxonomic and evolutionary studies. TAG Theoretical and Applied Genetics, 54(4), 145-151.

[3] Khan, M.K. (1990) Production and utility of chickpea
(Cicer arietinum L.) in Pakistan. Progressive Farming, 10(6), 28-33.

[4] Murphy, R.W., Sites, J.W., Buth, D.G. and Haufler, C.H. (1990) Protein isozymes electrophoresis. In: Molecular Systematic. Hillis, D.H. and Moritz, C., Eds., Sinnauer Association, Sunderland, Massachusetts, 45-126.

[5] Nakajima, K. (1994) Biotechnology for crop improvement in Japan. In: Biotechnology Application in Agricul ture in Asia and Pacific, Published by Asian Productivity Organization, 87-107.

[6] Ghafoor, A., Gulbaaz, F.N., Afzal, M., Ashraf, M. and Arshad, M. (2003) Inter-relationship between SDS-PAGE markers and agronomic traits in chickpea (Cicer arietinum L.). Pakistan Journal of Botany, 35(4), 613-624.

[7] Satija, D.R., Adrash, B., Gupta, S.K. and Bala, A. (2002) Genetic diversity in relation to protein and protein fractions in chickpea (Cicer arietinum L.). Crop-Improvement, 29(2), 122-135.

[8] Asghar, R., Siddique, T. and Afzal, M. (2003) Inter and intra-specific variation in SDS-PAGE electrophoregrams of total seed protein in chickpea (Cicer arietinum L.) germplasm. Pakistan Journal of Biological Sciences, 6(24), 1991-1995.

[9] Bradford, M. (1976) A rapid and sensitive method for the quantitayion of microgram quantities of protein utilizing the principle of protein-dye binding. Analytical Biochemistry, 72(1-2), 248-254.

[10] Olson, B.J.S.C. and Markwell, J. (2007) Assays for determination of protein concentration. Current Protocols in Protein Science, 3(4), 3.4.1-3.4.29.

[11] Hames, B.D. (1990) One-dimensional polyacrylamide gel electrophoresis. In: Hames, B.D. and Rickwood, D., Eds., Gel Electrophoresis of Proteins, 2nd Edition, Oxford University Press, New York, 382.

[12] Javid, A., Ghafoor, A. and Anwar, R. (2004) Seed storage protein electrophoresis in groundnut for evaluating genetic diversity. Pakistan Journal of Botany, 36(1), 25-29.

[13] Iqbal, S.H., Ghafoor, A. and Ayub, N. (2005) Relationship between SDS-PAGE markers and Ascochyta blight in chickpea, Pakistan Journal of Botany, 37(1), 87-96.

[14] Jha, S.S. and Ohri, D. (1996) Phylogenetic relationships of Cajanus cajan (L.) Millsp. (pigeonpea) and its wild relatives based on seed protein profiles. Genetic Resources and Crop Evolution, 43(3), 275-281.

[15] Seferoglua, S., Seferoglua, H.G., Tekintasa, F.E. and Baltab, F. (2006) Biochemical composition influenced by different locations in Uzun pistachio cv. (Pistacia vera L.) grown in Turkey. Journal of Food Composition and Analysis, 19(5), 461-465.

[16] De Vries, I.M. (1996) Characterisation and identification of Lactuca sativa cultivars and wild relatives with SDSelectrophoresis (Lactuca sect. Lactuca, Compositae), Genetic Resources and Crop Evolution, 43(3), 193-202.

[17] Gepts, P. (1989) Genetic diversity of seed storage proteins in plants. In: Brown, A.H.D., Clegg, M.T., Kahler, A.L. and Weir, B.S., Eds., Plant Population Genetics, Breeding and Genetic Resources, Sinauer Associates Inc., Sunderland, Massachusetts, 64-82.

[18] Khan, M.F., Schumann, E. and Weber, W.E. (2002) Characterization of Pakistani wheat varieties for general cultivation in the mountainous regions of Azad Kashmir. Asian Journal of Plant Sciences, 1(6), 699-702. 
[19] Zeb, A., Zahir, A., Ahmad, T. and Abdumanon, A. (2006) Physiochemical characteristics of wheat varieties growing in the same and different ecological regions of Pakistan. Pakistan Journal of Biological Sciences, 9(9), 1823-1828.

[20] Magni, C., Scarafoni, A., Herndl, A., Sessa, F., Prinsi, B., Espen, L. and Duranti, M. (2007) Combined 2D electrophoretic approaches for the study of white lupin mature seed storage proteome. Phytochemistry, 68(7),
997-1007.

[21] Sadia, M., Salman, A.M., Rabbani, M.A. and Pearce, S.R. (2009) Electrophoretic characterization and the relationship between some Brassica species. Electronic Journal of Biology, 5(1), 1-4.

[22] Das, S. and Mukherjee, K.K. (1995) Comparative study on seed proteins of Ipomoea. Seed Science and Technology, 23(2), 501-509. 